\title{
The role of government policies in the proliferation of multinational business
}

\author{
Valentina Golea, University Politehnica of Bucharest \\ Nicoleta Niculescu*, University Politehnica of Bucharest \\ Dragoş Filip Niculescu , Economist
}

\begin{abstract}
The different components of the governmental policy have a significant influence over the foreign companies` activity.

The economic policies include the fiscal policy, monetary policy, commercial policy and sector policy. For transnational society, the most influential governmental actions are those regarding economic restriction like: exchange control, import restrictions, taxes control, price control, the local matters restrictions, foreign investments ' restrictions.

Knowing the host country's global political climate (anticipating changes that might appear in time) and its involvement in a larger frame of the world's political context will offer to the company the possibility of a correct underlying and adaption of its own international strategy according to the concret conditions of the political space where it will operate.
\end{abstract}

\section{Keywords}

government policies, multinational business, political risk, multinational companies, political instability, host country

JEL Codes: F23, F29, F42

\section{Introduction}

Some countries' attitude towards foreign companies is more open than others. Some countries are open to external collaboration, while others are very conservative, accepting foreign products slower, and sometimes promote an exaggerated protectionism and nationalism.

The host country's national security policies limit or even prohibit the foreign companies' access into " key sectors". At the same times, in accordance with foreigh policies, the host governments can favor the access to strategic sectors by companies that originate from certain countries.

That is why, for a realistic substantiation of its expansion strategy, the company must analyze the host country's foreign policy, especially the diplomatic relations between the host country and its country of origin. If there are certai conflicts (economical, political or military) or tense relations between the two countries, deterioration of relations is anticipated, the companies will look at other foreign markets where adequate or even preferential treatment will be give to them.

An isolation policy promoted by the host country is not preferred by the foreign company because this isolation reflects indirectly on its activities, restricting it to the local market and creating difficulties with market penetration and external supply lines. All these economic or 
noneconomic policy elements promoted by the host country's government will have different consequences for the transnational company's future activity.

\section{The importance of stability policies government}

All countries, no matter if developed or developing, seek macroeconomic stability through monetary, fiscal and predictable earning politics, fighting against negative phenomena that the economy is dealing with (inflation, unemployment etc).

The general economic policy depends on the host country's government form, specifically the states' involvement in the economy (as an example, a government with radical political orientation will insist on the government strong presence in the economical environment).

The stability or instability of the host countey's government is of maximum importance to international companies. Political risk in international affairs increases when difficulties within the business environment are hard to anticipate as a result of political change. Radical changes that appear after periods of relative stability pose the highest risk. Such changes mark a country's government policy as instable, capable of diminishing the investment process. Instabilty can result from a change of the type of government or the political parties that are governing ; another possible situation consists of the form of government staying the same, but a dramatic change of foreigh policy being passed by law.

The most drastic changes in government business relations appear the form of government is changed. The new government may promote a new politicy of "aggressively exploiting foreign companies ". In this case, some markets` potential may be diminished ; even so, certain foreign companies may register profitable investments in this country, but only in certain fields.

The governments' high instability and the difficulty of anticipating change in the government's polities deteriorate investment opportunities. The political risk refers to the possibility of political decisions, events and conditions from one country affecting the business climate in such a manner that the investors lose money or do not reach the profit margin expected .

For a company with overseas activity, the risk generated by political implications vary, the most noticeable being: seizure, expropriation and nationalization, special operating rules for foreighn investors, embargo, boycott etc. to be considered a risk, political change have to be capable of negatively influencing the company's profits or objectives. Political specialists have created stability indices, in order to better anticipate the risk that countries pose. Such an index has been created by "Political Risk Services", offering the possibility of political risk evaluation with regard to a classification system that reflects (Bradley, F., 2001: pp 181): 1. Restrictions regarding profit, capital repatriation or currency control ;

2. Delayed payments to exporters ;

3. The policy referring to monetary and fiscal expansion ;

4. Foreign loans made by the government.

The countries are graded for each risk category, and then classified in four categories, from A (countries with the lowest risk) to D (countries with the highest risk).

Some public sources publish periodic lists regarding countries hierarchy on the political risk scale (Sasu, C, 1998: pp 91) : for example, the British magazine The Economist publishes on every trimester a hierarchy of countries that considers 27 influence factors, the highest risk being attributed 100 points ; the American publication International Country Risk Guide is assesses these risk monthly. The factors that are taken into account are: government corruption, birocracy, legislation tradition, the risk of external conflicts, political terrorism, political leadership, economical planning failures and the rate of fulfillment of economical predictions.

In order to diminish political risk, some measures can be taken, such as finding some means of cooperation with local companies. 


\section{Various types of government attitude towards multinational companies}

When speaking of democratic governments (parliamentary) the public opinion has relatively an important role in fundament the government's policy, it has to fin dit self, with the political parties' help, in the process of adopting legislative and administrative measures. It is generally known that political parties influence the government's activities regarding the policy towards foreign companies. The political parties system can be classified in: two-party system, multi-party, single-party and the system dominated by one party.

When speaking of the two-party system it is important to study the impact made by the sucession of different parties at governing on the foreign companies' actinvity and their relation witn the government in charge.

In a multi-party system, no party is strong enough to dominate and control the formed government which as a consequence is a majority coalition incorporating an amalgam of parties.

Regarding the multi-party system this suffers frequent modifications caused by changes in the structure of the governmental coalition, the longevity of such a coalition being dependent on the collaboration and cooperation which exist between each of the partners. Such a system is best represented in Italy, but it can also be seen in Germany, France, Belgium, Holland and even Romania.

A single-party system where is no opposition and the government party inhibits other parties' genesis and development, and also their activity. This can have a negative effect over foreign companies' activity, and in this case political competition is excluded, the system can very easily transform itself in a dictatorial system. A system dominated by only one party is the system where no other party is strong engough to win control of the government. This is a situation encountered especially in the countries when the parliamentary system is found in the formation phase, but as the system matures yhe transformation to a multi-party system takes place.

For the company decided to globalize its affairs it is important to know the government's attitude towards foreign companies' activity on its national territory. The political parties' position is as important as the government's attitude in this matter, because any of them can succeed to govern or the philosophy of an opposing party or parties.

\section{Conclusion}

In order to fully and completely understand the host country's political situation and its stability it is necessary for the guest country`s manager to evaluate the political stability.

Political instability can also be generated by the loss of the government's political support of certain formation (specifically to the coalition governments).The involvement of the population on a large scale in electing managerial political structures can diminish or on the contrary, magnify legislative and executive fragmentation of the political body and political instability related to political preferances' homogeneity/heterogeneity expressed by the electorate.

In order to evaluate present instability, the foreign company wishing to expand its activities on a new market will look at, alongside with earlier mentioned elements, onther factors like: frequency of strikes and street demonstrations, and the frequency of antigovernment and political manifestations, terrorism acts' frequency, governmental crisis frequency, irregularity of political changes and coups.

Making this analysis, the company will try to predict the future evolution of these factors, and related to them the future political instability. So, the native country's political instability 
determines the company to turn its activity overseas, to other markets, and the host country's high political instability discourages foreign companies' investments and activities on the country's territory, politically speaking, a stable host country is preferred.

A company, in order to be aware of its vulnerability towards the host country's political climate, has to always have in mind that the company is a guest and has to act according to this statute. The company's profits are not owned exclusively by it, the local work force and the host country's economy have to have some advantages for allowing the company to invest. At the same time the foreign company has to be part of the host country's economy through public interest projects, the foreign personnel have to adapt to the new environment conditions they will work in. Also, it is recommended not to administer the investment from the "main centre", but through the local managerial competencies' involvement, only procedures supervision should be made from the centre.

In order to get the side of the host countries' governments, foreign companies can take part in economical and cultural project of public interest.

\section{References}

1. Bradley, F., 2001, Marketing International, Ed. Teora, Bucureşti

2. Fatehi, Kamal, 1996, International Management, Prentice Hall

3. Golea,Valentina, 2008, Managementul afacerilor multinaționale, Ed. Bren

4. Mockler, R., 2001, Management strategic multinațional, Ed. Economică

5. Niculescu, M., Lavalette, G, 2003 ., Strategii de creştere, Ed. Economicã, Bucureşti

6. Sasu, C., 1998, Marketing Internațional, Ed. Polirom , Iaşi 